\title{
МОДИФІКАТОР ВАЖКИХ ПАЛИВНИХ СУМІШІВ
}

\section{Сандлер А.К.}

Національний університет «Одеська морська академія», м. Одеса, Україна

E-mail: albertsand4@gmail.com

Copyright (C) 2018 by author and the journal “Automation technologies and business - processes. This work is licensed under the Creative Commons Attribution International License (CC BY). http://creativecommons.org/licanses/by/4.0

ONAFT

Open Access

DOI:

Анотація: Зменшення витрат усіх видів палив може значно поліпшити екологічну ситуачію за рахунок зменшення викиду в атмосферу забруднюючих і токсичних продуктів згоряння палива і зменшення споживання кисню з повітря. Це, в свою чергу, повинно зменшити економічні втрати, пов'язані з природоохоронними заходами, обумовленими роботою транспорту і енергетичних об'єктів. Саме тому розробка засобів, щзо дозволяють більш ефективно використовувати вуглеводневе паливо в суднових енергетичних установках, на морському транспорті, $\epsilon$ системоутворюючим фактором його розвитку.

У той же час, застосування існуючих пристроїв виявило їх недостатню стійкість до впливу неконтрольованих дестабілізуючих факторів, щзо генеруються компактно розташованими об 'єктами суднової енергетичної установки. Для пошуку шляхів поліпшення характеристик пристроїв модифікації властивостей та структури палив проаналізовані конструкиії найпоширеніших конструкиій.

В умовах, щуо склалися, дочільною стала розробка нового схемотехнічного рішення модифікатора. Для розв 'язування поставленої задачі запропонована схема модифікатора паливних сумішів.

Під впливом тиску, що створюється паливним насосом високого тиску, паливо надходить до корпусу розпилювача та потрапляє у вхід каналів особливого рельєфу та до незворотного клапану. У каналах, завдяки складному профілю, щзо характеризується варіативною геометрією по кроку, профілю та глибині, відбуваються процес деструкиії внутрішньої структури палива, щзо рухається з субзвуковою швидкістю. У паливі, щуо потрапляє крізь незворотній клапан до об 'єму втулки, відбувається мікроелектрогідравлічний удар.

За рахунок багаточисельних гідравлічних ударів, щз виникають при просуванні палива крізь канали, щзо характеризуються значною кількістю поворотів, та шайби генеруються дефект структури паливної сумімі. Після мікроелектрогідравлічного удару та проходження каналів й сопел Лаваля відбувається прочес генерації дефектів структури важкого палива. Дефекти, щуо виникають, являють собою розрив у безперервної орієнтації, тобто розрив у полі директора $n(r)^{2}$. Завдяки таким розривам утворюються краплі лінійним розміром який не перебільшує 20 мкм при виході з сопла форсунки. Розпилювання палива з таким лінійним розміром дозволяє отримати більшу поверхню згоряння та поліпшити якість робочого прочесу.

Abstract: Reducing the cost of all types of fuels can greatly improve the environmental situation by reducing the emission of polluting and toxic combustion products into the atmosphere and reducing the consumption of oxygen from the air. This, in turn, should reduce the economic losses associated with environmental measures imposed by the work of transport and energy facilities. That is why the development of tools that allow more efficient use of hydrocarbon fuels in marine power plants, on sea transport, is a system-forming factor for its development.

At the same time, the use of existing devices revealed their insufficient resistance to the uncontrolled destabilizing factors generated by the compactly located objects of the ship's power plant. In order to find ways to improve the characteristics of the devices for the modification of properties and structure of fuels, the designs of the most common designs are analyzed.

In the prevailing conditions, it was expedient to develop a new circuit design modifier solution. For the solving of the task, a scheme of the modifier of fuel mixtures is proposed.

Under the influence of pressure created by the fuel pump of high pressure, fuel enters the body of the sprayer and enters the entrance of the channels of a special relief and to an irreversible valve. In the channels, due to the complex profile, characterized by variational geometry along the step, profile and depth, there is a process of destruction of the internal structure of the fuel moving at a sub-sound velocity. In the fuel that enters through the non-return valve to the volume of the sleeve, a microelectrohydraulic blow occurs. 
http://www.atbp.onaft.edu.ua/

Due to the numerous hydraulic shocks that arise when the fuel is propelled through channels characterized by a significant number of turns, and the washer generates a defect in the structure of the fuel mixture. After the microelectrohydraulic blow and passage of Laval's canals and nozzles, the process of generating defects in the structure of heavy fuel is taking place. The emerging defects represent a gap in the continuous orientation, that is, the gap in the director's field $n$ ( $r)^{2}$. Due to such discontinuities, droplets of linear size do not exceed 20 microns when exiting the nozzle nozzle. Sawing fuel with such a linear size allows you to get a larger combustion surface and improve the quality of the workflow.

Ключові слова: модифікатор, паливо, гідравлічний удар

Key words: modifier, fuel, hydraulic impact

\section{1. Вступ}

Сьогодні проблема енергоефективності та енергозбереження розглядається як найважливіший аспект проектування, створення і використання морських і річкових суден. Це обумовлено як збільшенням кількості судів в світовому судноплавстві, так і зростанням потужності суднових енергетичних установок. В силу величезної протяжності морських комунікацій світова економіка не може успішно розвиватися без випереджаючого розвитку транспортної системи, яка є одним з основних споживачів копалин паливних ресурсів і, перш за все, нафти.

Зменшення витрат усіх видів палив може значно поліпшити екологічну ситуацію за рахунок зменшення викиду в атмосферу забруднюючих і токсичних продуктів згоряння палива і зменшення споживання кисню 3 повітря. Це, в свою чергу, повинно зменшити економічні втрати, пов'язані з природоохоронними заходами, обумовленими роботою транспорту і енергетичних об'єктів.

Саме тому розробка засобів, що дозволяють більш ефективно використовувати вуглеводневе паливо в суднових енергетичних установках, на морському транспорті, є системоутворюючим фактором його розвитку.

Для зміни властивостей паливних сумішів застосовується широкий спектр пристроїв на основі різноманітних фізичних принципів роботи, які серійно виробляються промисловістю.

\section{2. Аналіз літературних джерел і постановка питання}

У той же час, застосування існуючих пристроїв виявило їх недостатню стійкість до впливу неконтрольованих дестабілізуючих факторів, що генеруються компактно розташованими об’єктами суднової енергетичної установки [1, $2,3]$.

Для пошуку шляхів поліпшення характеристик пристроїв модифікації властивостей та структури палив проаналізовані конструкції найпоширеніших конструкцій $[3,4,5]$.

Відомий п`зоелектричний модифікатор, який складається 3 корпусу-фіксатора, двох напівциліндричних п'єзоелектричних силових елементів, що накладаються зовні на трубопровід, ліній живлення та п’єзоелектричного модулятора [4] (рис. 1).

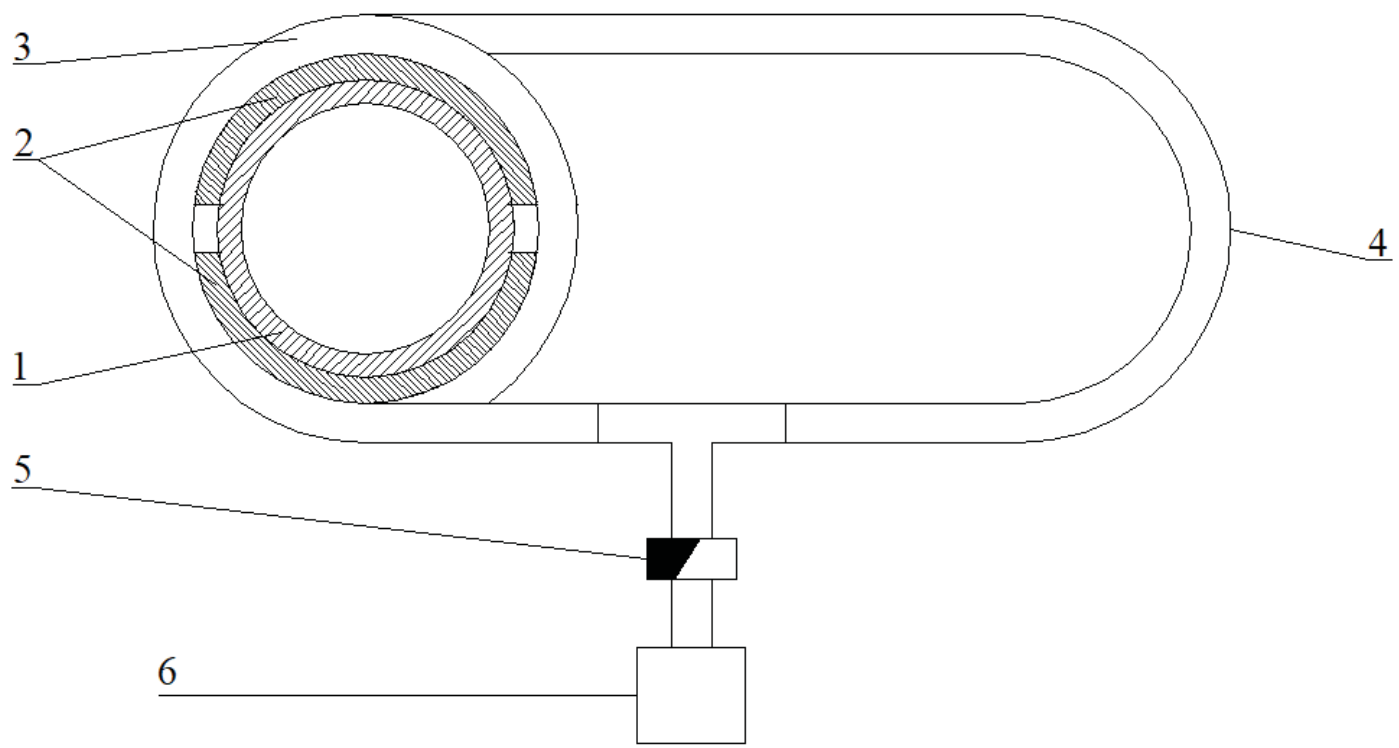

Рис. 1 - П`єзоелектричний модифікатор: 1 - паливний трубопровід; 2 - напівциліндричні п’єзоелектричні силові елементи; 3 - корпус-фіксатор; 4 - лінії живлення; 5 - п’єзоелектричний модулятор; 6 - блок живлення.

Недоліки пристрою, які обумовлені використанням п`єзоматеріалів: 
наявність елементів, виконаних з матеріалів з коефіцієнтами теплового поширення, що відрізняються один від одного;

неможливість застосування при температурах палива понад $120^{\circ} \mathrm{C}$;

неможливість наближення пристрою до місця вприску палива у робочий циліндр;

підвищена пожежонебезпечність пристрою.

У меншій мірі експлуатаційні та конструктивні фактори впливають на характеристики пристрою, що містить корпус розпилювача, шайби перемінного діаметру, канали рельєфу особливого профілю на корпусі розпилювача та зовнішньому боці шайб [5] (рис. 2).

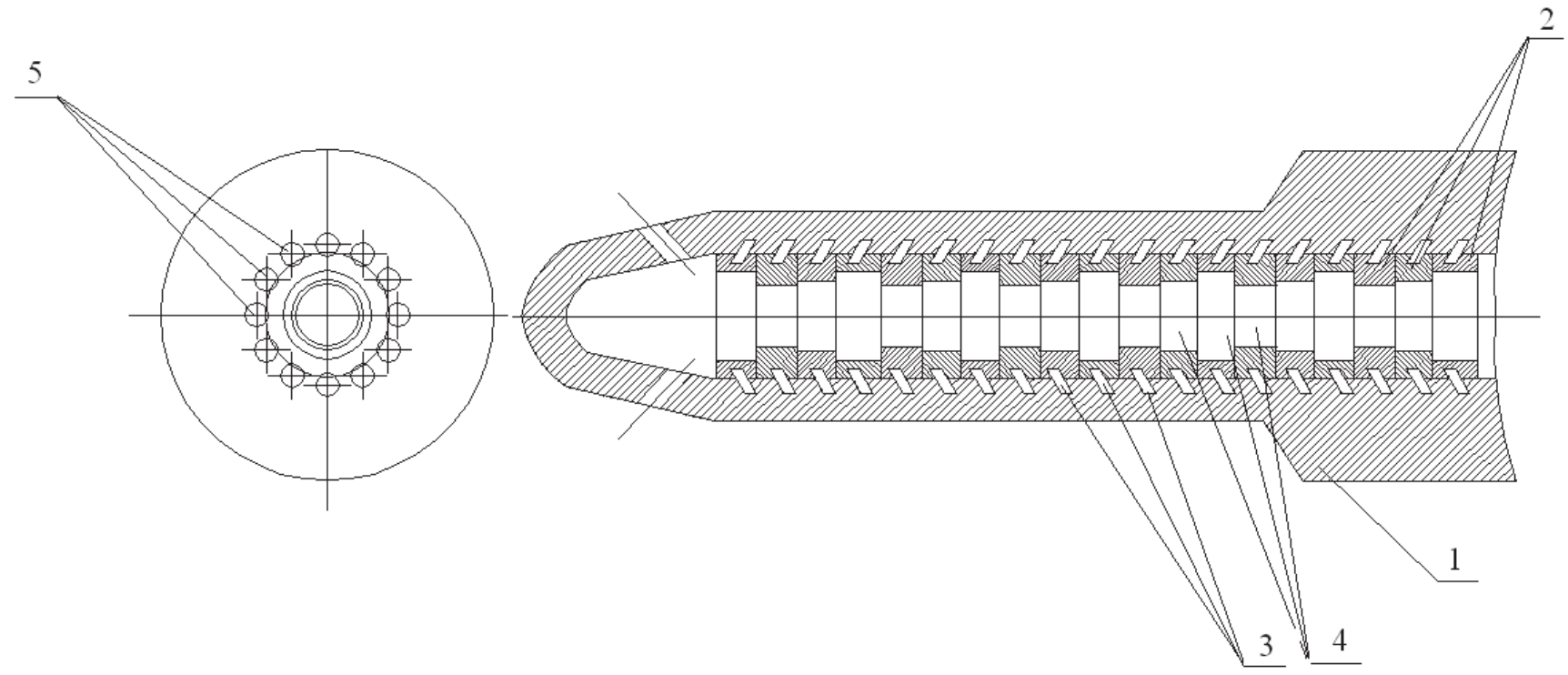

Рис. 2 - Модифікатор структури важкого палива: 1 - корпус розпилювача; 2 - шайби; 3 - канали рельєфу особливого профілю на корпусі розпилювача зовнішньому боці шайб та; 4 - перемінний прохідний діаметр шайб; 5 - вхід каналів особливого профілю.

Недоліки пристрою, які обумовлені використанням шайб перемінного діаметру:

швидке коксування шайб важкими фракціями палива;

втрата пристроєм своїх властивостей деструкції паливних сумішей після коксування;

необхідність ретельного та частого очищення пристрою;

необхідність прецизійного складання пристрою після регламентних робіт.

\section{3. Мета і задачі дослідження}

В умовах, що склалися, доцільною стала розробка нового схемотехнічного рішення модифікатора. Передбачалося, що конструктивне виконання повинне забезпечити пристрою:

відсутність порушення цілісності паливного трубопроводу,

відсутність прецизійних регламентних робіт;збереженість температурного діапазону та ступені деструкції структури палива відомих типів модифікаторів.

Для розв `язвання поставленої задачі запропонована схема модифікатора паливних сумішів.

Суть запропонованого схемотехнічного рішення пояснюється кресленням (рис. 3).

\section{4. Основні пункти дослідження}

Модифікатор, що складається 3 каналів 3, які сформовані на внутрішньому боці отвору для палива корпусу розпилювача 1 у вигляді рельєфу особливого профілю, та втулки 23 верхньою 4 та нижньою 7 кришками, вмонтованих у отвір для палива розпилювача, які також мають на зовнішньому боці канали 3 у вигляді рельєфу особливого профілю. У верхній кришці змонтований незворотній клапан 5 з пружиною 6. А у нижній кришці виконано 12 отворів у формі сопла Лаваля. До корпусу модифікатора підключений вихід від електричної схеми створення мікроелектрогідравлічного удару, яка складається з зарядного опору 9 , трансформатора 10 , випрямляча 11 , конденсатора 12, проміжку, утворюючого іскру 13, електрода 3 ізоляцією 14. Електрод введено до внутрішнього простору втулки від входу електросхеми. 


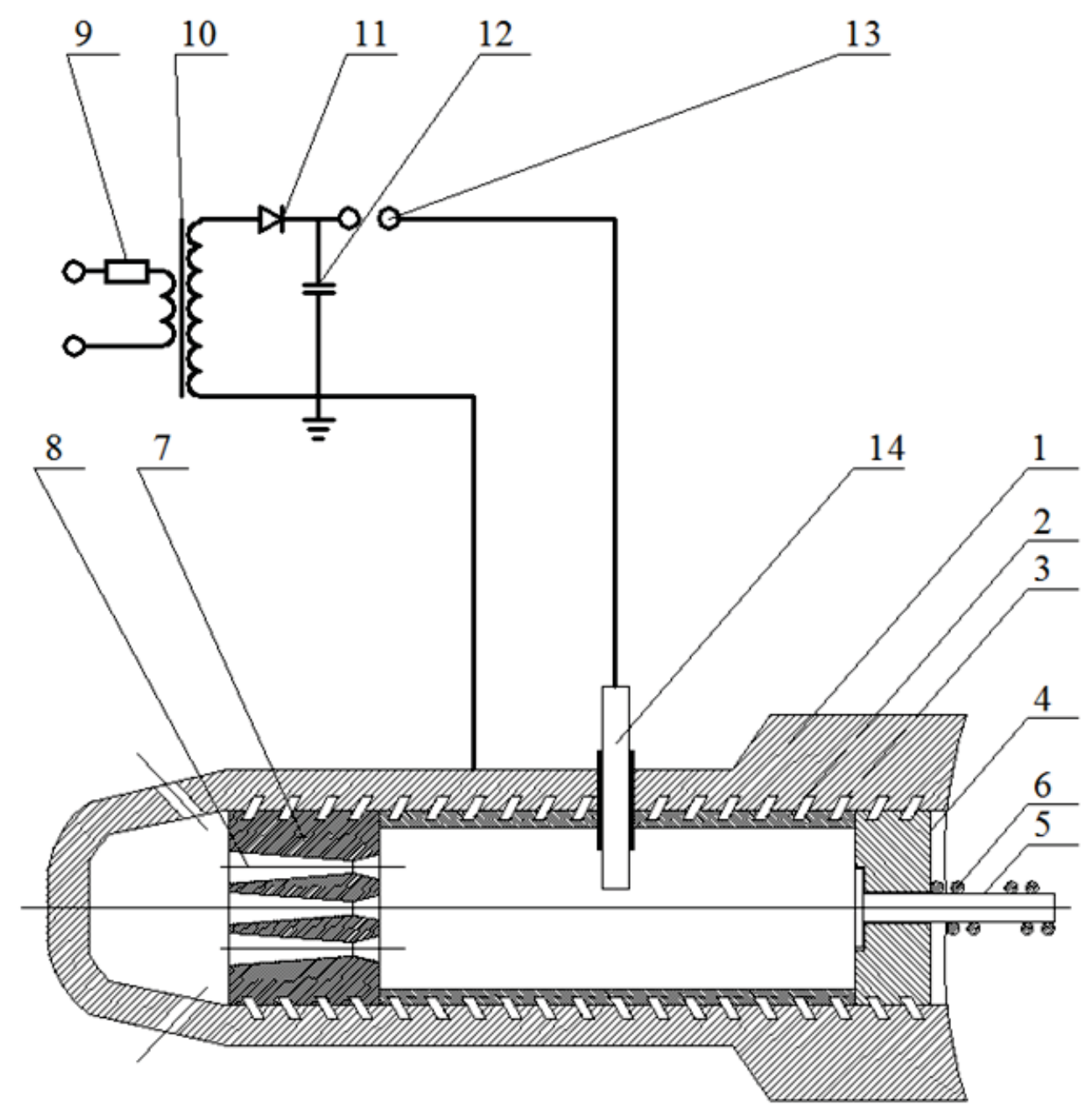

Рис. 3 - Модифікатор структури важкого палива: 1 - корпус розпилювача; 2 - втулка; 3 - канали рельєфу особливого профілю на корпусі розпилювача та зовнішньому боці шайб; 4 - верхня кришка; 5 - незворотний клапан; 6 - пружина; 7 - нижня кришка; 8 - сопло Лаваля; 9 - зарядний опір; 10 - трансформатор; 11 - випрямляч; 12 - конденсатор; 13 проміжок, утворюючий іскру; 14 - електрод 3 ізоляцією.

Елементи модифікатора для збереження необхідних робочих зазорів виконуються безпосередньо на деталях паливних форсунок без порушення міцності і цілісності елементів паливної системи, що функціонують під підвищеним тиском паливної суміші.

Під впливом тиску, що створюється паливним насосом високого тиску, паливо надходить до корпусу розпилювача та потрапляє у вхід каналів особливого рельєфу та до незворотного клапану. У каналах, завдяки складному профілю, що характеризується варіативною геометрією по кроку, профілю та глибині, відбуваються процес деструкції внутрішньої структури палива, що рухається з субзвуковою швидкістю. У паливі, що потрапляє крізь незворотній клапан до об’єму втулки, відбувається мікроелектрогідравлічний удар.

Після мікроелектрогідравлічного удару та проходження каналів й сопел Лаваля відбувається процес дисклинації (генерації дефектів структури) важкого палива. У наслідок цього процесу формуються краплі з лінійним розміром який не перебільшує 20 мкм при виході з сопла форсунки. При розпилюванні важких паливних сумішів 3 лінійним розміром краплі, який не перебільшує 20 мкм, досягається їх більш повне та якісне згоряння у циліндрі дизеля.

Для здійснення винаходу застосовано комбінацію каналів рельєфу особливого профілю на корпусі розпилювача й зовнішньому боці набору втулки, сопел Лаваля у нижній кришці, а також електричної схеми для створення мікроелектрогідравлічного удару.

Під впливом тиску, що створюється паливним насосом високого тиску, паливо надходить до корпусу розпилювача та потрапляє у вхід каналів особливого рельєфу та до незворотного клапану. У каналах, завдяки складному профілю, що характеризується варіативною геометрією по кроку, профілю та глибині, відбуваються процес деструкції 
внутрішньої структури палива, що рухається з субзвуковою швидкістю. У паливі, що потрапляє крізь незворотній клапан до об’єму втулки, відбувається мікроелектрогідравлічний удар.

За рахунок багаточисельних гідравлічних ударів, що виникають при просуванні палива крізь канали, що характеризуються значною кількістю поворотів, та шайби генеруються дефект структури паливної суміші.

Після мікроелектрогідравлічного удару та проходження каналів й сопел Лаваля відбувається процес дисклинації (генерації дефектів структури) важкого палива.

Дефекти, що виникають, являють собою розрив у безперервної орієнтації, тобто розрив у полі директора $n(r)^{2}[6]$. Завдяки таким розривам утворюються краплі лінійним розміром який не перебільшує 20 мкм при виході 3 сопла форсунки. Розпилювання палива 3 таким лінійним розміром дозволяє отримати більшу поверхню згоряння та поліпшити якість робочого процесу.

Запропоноване схемотехнічне рішення відрізняється тим, що втулка на верхньому кінці має кришку, у які вмонтовано незворотній клапан, на нижньому кінці втулки кришка має перфорацію у вигляді сопел Лаваля, а сама втулка залучена до електричної схеми створення електрогідравлічного удару [7].

\section{5. Висновки}

Таким чином, в розробленому пристрою комбінація електромеханічних елементів забезпечує:

більш ефективну генерацію дефектів структури паливної суміші;

компенсацію впливу дестабілізуючих факторів на робочий канал модифікатору;

наближення модифікатору до місця вприску палива у робочий циліндр;

підвищення якості функціювання за рахунок використання матеріалів з близьким коефіцієнтом теплового поширення.

Застосування запропонованої моделі пристрою, крім того, дозволить підвищити безпеку і ефективність різних типів технологічних процесів у суднової енергетичної установці і судні в цілому.

\section{Список використаних джерел}

[1] Двигатели внутреннего сгорания: Системы поршневых и комбинированных двигателей. /С.И. Ефимов, Н.А. Иващенко, В.И. Ивин и др.; под общей ред. А.С. Орлина, М.Г. Круглова. - М.: Машиностроение, $1985 .-456$ с.

[2] Овсянников М.К. Судовые дизельные установки: Справочник / М.К. Овсянников, В.А. Петухов // - Л.: Судостроение, 1986. - 424 с.

[3] Шарапов В.М. Пьезоэлектрические датчики / В.М. Шарапов, М.П. Мусиенко, Е.В. Шарапова // Под ред. В.М. Шарапова. - М.: Техносфера, 2006. - 632 с.

[4] Добровольский В.В. Энергетические затраты на топливоподготовку судовых малооборотных двигателей / В.В. Добровольский, Л.В. Пизинцали // Проблеми техніки: наук.-техн. збірн. - 2010. - Вип. 3. - Одеса: ОНМУ. - С. $129-137$.

[5] Деклараційний патент на корисну модель № 78834 Україна, МПК (2013.01): G01M 11/00. Модифікатор важких паливних сумішей / В.В. Добровольський, С.А. Ханмамедов; заявники та володарі патенту В.В. Добровольський, С.А. Ханмамедов. - № u201203661; заявл. 26.03.2012; опубл. 10.04.2013, бюл. №. - 3 с.

[6] П. де Жен. Физика жидких кристаллов // Перевод с английского А.А. Веденова. /Под редакцией А.С. Сонина. М.: Мир, 1977. - 400 с.

[7] Сандлер, А.К., Цюпко, Ю.М. Модифікатор важких паливних сумішей. Деклараційний патент України № 119383. МПК (2006): F02B 77/00, В60K 15/00- заявл. 30.03.2017. // Опубл. 25.09.2017, бюл. № 18/2017.

\section{References}

[1] S.Y. Efymov, N.A. Yvashchenko, V.Y. Yvyn y dr., Dvyhately vnutrenneho shoranyia: Systemy porshnevikh y kombynyro-vannsblkh dvyhatelei. Pod obshchei red. A.S. Orlyna, M.H. Kruhlova. M.: Mashynostroenye. - 456 s. , 1985.

[2] Ovsiannykov, M.K., Petukhov, V.A., Sudovse dyzelnye ustanovky: Spravochnyk. L.: Sudostroenye. - 424 s., 1986.

[3] Sharapov, V.M., Musyenko, M.P., Sharapova, E.V., Pezoelektrycheskye datchyky. Pod red. V.M. Sharapova. M.: Tekhnosfera. - 632 s., 2006.

[4] V.V. Dobrovolskyi, L.V. Pyzyntsaly, Enerhetycheskye zatraty na toplyvopodhotovku sudovskh malooborotnskh dvyhatelei. Problemy tekhniky: nauk.-tekhn. zbirn. Vyp. 3. Odesa: ONMU. - S. 129 - 137., 2010.

[5] V.V. Dobrovolskyi, S.A. Khanmamedov; zaiavnyky ta volodari patentu V.V. Dobrovolskyi, S.A. Khanmamedov, Deklaratsiinyi patent na korysnu model № 78834 Ukraina, MPK (2013.01): G01M 11/00. Modyfikator vazhkykh palyvnykh sumishei. - № u201203661; zaiavl. 26.03.2012; opubl. 10.04.2013, biul. №. - 3 s.

[6] P. de Zhen., Fyzyka zhydkykh krystallov. Perevod s anhlyiskoho A.A. Vedenova. Pod redaktsyei A.S. Sonyna. - M.: Myr. - 400 s., 1977.

[7] Sandler, A.K., Tsiupko, Yu.M. Modyfikator vazhkykh palyvnykh sumishei. Deklaratsiinyi patent Ukrainy № 119383. MPK (2006): F02B 77/00, B60K 15/00- zaiavl. 30.03.2017. // Opubl. 25.09.2017, biul. № 18/2017. 